\author{
Anna Spoz \\ Katolicki Uniwersytet Lubelski Jana Pawła II, \\ Wydział Nauk Społecznych, Katedra Instytucji i Rynków Finansowych \\ e-mail: aspoz@kul.lublin.pl
}

\title{
ROLA I ZNACZENIE KOMITETU AUDYTU W JEDNOSTKACH ZAINTERESOWANIA PUBLICZNEGO
}

\section{THE ROLE AND IMPORTANCE OF THE AUDIT COMMITTEE IN PUBLIC INTEREST ENTITIES}

DOI: $10.15611 /$ pn.2018.531.37

JEL Classification: M41, M42, M48

Streszczenie: W Polsce obowiązek wyłonienia komitetu audytu w ramach rady nadzorczej jednostki zainteresowania publicznego istnieje od 7 maja 2009 r. Do tego czasu było to jedynie zalecenie zawarte $\mathrm{w}$ dokumentach poświęconych zasadom ładu korporacyjnego. W 2017 r. wspomniana ustawa została zastąpiona Ustawą z dnia 11 maja 2017 r. o biegłych rewidentach, firmach audytorskich oraz nadzorze publicznym. Celem artykułu jest prezentacja zadań komitetu audytu działającego w ramach rady nadzorczej jednostki zaufania publicznego oraz identyfikacja i omówienie wyzwań przed nim stojących. Jako narzędzia badawcze wykorzystano krytyczną analizę literatury obejmującą akty normatywne, metodę opisu, syntezy i dedukcji. W pierwszej części artykułu przedstawiono zadania komitetu audytu wynikające z obecnie obowiązującej ustawy. Następnie na podstawie raportu KNF prezentującego wyniki badań nad zgodnością sprawozdań finansowych emitentów papierów wartościowych z zasadami raportowania finansowego, tym MSSF, przeanalizowano ich jakość i najczęściej popełniane błędy.

Słowa kluczowe: jednostki zainteresowania publicznego, audyt, sprawozdanie finansowe.

Summary: In Poland, the obligation to select an audit committee within the supervisory board of a public interest entities has been from 7 May 2009. Until now, it has only been recommendation contained in the documents on the principles of corporate governance. In 2017 , the Act of $11 / 05 / 2017$ on statutory auditors, audit firms and public supervision entered into force. The aim of the article is to discuss the tasks of the audit committee operating in the public trust unit and to identify and discuss the challenges the committee is facing. As a research tools, the analysis of subject literature including legal regulations, a method of description, synthesis and deduction was used. The first part of the article discusses the tasks of the audit committee resulting from current law. Then, based on a report of Polish Financial Supervision Authority 's titled"Enforcement of the financial reporting of securities issuers carried out in 2017" their quality and the most common mistakes were analyzed.

Keywords: public-interest entities, audit, financial statement. 


\section{Wstęp}

Komitet Audytu jest stałym komitetem rady nadzorczej pełniącym funkcję pomocniczą. Do maja 2009 r. jego powołanie uzależnione było od wewnętrznych regulacji spółki, choć rekomendacje w tym zakresie zostały zawarte w dokumentach: „Dobre praktyki w spółkach publicznych 2005” oraz „Dobre Praktyki Spółek Notowanych na GWP” z 2008 r. Dziś na skutek wzrostu świadomości znaczenia sprawozdawczości finansowej jako źródła wiedzy o przedsiębiorstwie utworzenie komitetu audytu w podmiotach tak ważnych społecznie i gospodarczo, jak jednostki zainteresowania publicznego, stało się obligatoryjne.

Celem artykułu jest przedstawienie zadań, jakie ustawodawca postawił przed komitetem audytu działającym w ramach rady nadzorczej jednostki zaufania publicznego oraz identyfikacja i omówienie wyzwań przed nim stojących.

Metodami badawczymi wykorzystanymi w niniejszym opracowaniu były: krytyczny przegląd literatury przedmiotu obejmujący w głównej mierze akty normatywne, metoda opisu, analizy i syntezy. Wybrane treści zostały zaprezentowane $\mathrm{w}$ formie graficznej.

\section{Zadania komitetu audytu $w$ jednostkach zainteresowania publicznego}

Pojęcie jednostki zainteresowania publicznego zostało zdefiniowane w art. 2 ust. 9 Ustawy z dnia 11.05.2017 r. o biegłych rewidentach, firmach audytorskich oraz nadzorze publicznym [Ustawa z dnia 11 maja 2017 r.]. W Polsce liczba tych jednostek wynosi około 1300 przedsiębiorstw, a ich szczegółowy wykaz dostępny jest na stronach internetowych Ministerstwa Finansów.

Obowiązek wyłonienia komitetu audytu w ramach rady nadzorczej jednostki zainteresowania publicznego został wprowadzony ustawą z dnia 7 maja $2009 \mathrm{r}$. o biegłych rewidentach i ich samorządzie, podmiotach uprawnionych do badania sprawozdań finansowych oraz o nadzorze publicznym [Ustawa $\mathrm{z}$ dnia 7 maja 2009 r.]. W ubiegłym roku na skutek dostosowywania prawa polskiego do rozporządzenia Parlamentu Europejskiego i Rady (UE) nr 537/2014 ww. ustawa została zastąpiona Ustawą z dnia 11 maja 2017 r. o biegłych rewidentach, firmach audytorskich oraz nadzorze publicznym. Zgodnie $\mathrm{z}$ jej zapisami $\mathrm{w}$ jednostkach zainteresowania publicznego funkcjonuje komitet audytu zajmujący się sprawami audytu, a jego członkowie powoływani są przez radę nadzorczą lub inny organ nadzorczy lub kontrolny spośród członków tego organu [Ustawa z dnia 11 maja 2017 r., art. 128 ust. 1]. Odstępstwo od tego wymogu zawiera w art. 128 pkt 4, który bankom spółdzielczym, spółdzielczym kasom oszczędnościowo-kredytowym, jednostkom samorządu terytorialnego będącym jednostkami zainteresowania publicznego oraz innym jednostkom zainteresowania publicznego, które na koniec danego roku ob- 
rotowego oraz na koniec roku obrotowego poprzedzającego dany rok obrotowy nie przekroczyły co najmniej dwóch z trzech następujących wielkości, tj. 17000000 w przypadku sumy aktywów bilansu, przychodów netto ze sprzedaży towarów i produktów w wysokości 34000000 zł, oraz 50 osób w przypadku średniorocznego zatrudnienia w przeliczeniu na pełne etaty, daje możliwość powierzenia zadań komitetu audytu radzie nadzorczej lub innemu organowi nadzorczemu lub kontrolnemu jednostki zainteresowania publicznego [Ustawa z dnia 11 maja 2017 r., art. 128 ust. 4].

Listę zadań stojących przed komitetem audytu zawiera art. 130 niniejszej ustawy. Katalog ten nie jest jednak zamknięty. Ustawodawca w pierwszej kolejności zobowiązał komitety audytu do monitoringu trzech wzajemnie ze sobą powiązanych obszarów: sprawozdawczości finansowej jednostki, skuteczności systemów kontroli wewnętrznej, systemów zarządzania ryzykiem i audytu wewnętrznego oraz wykonywania czynności rewizji finansowej (rys. 1).

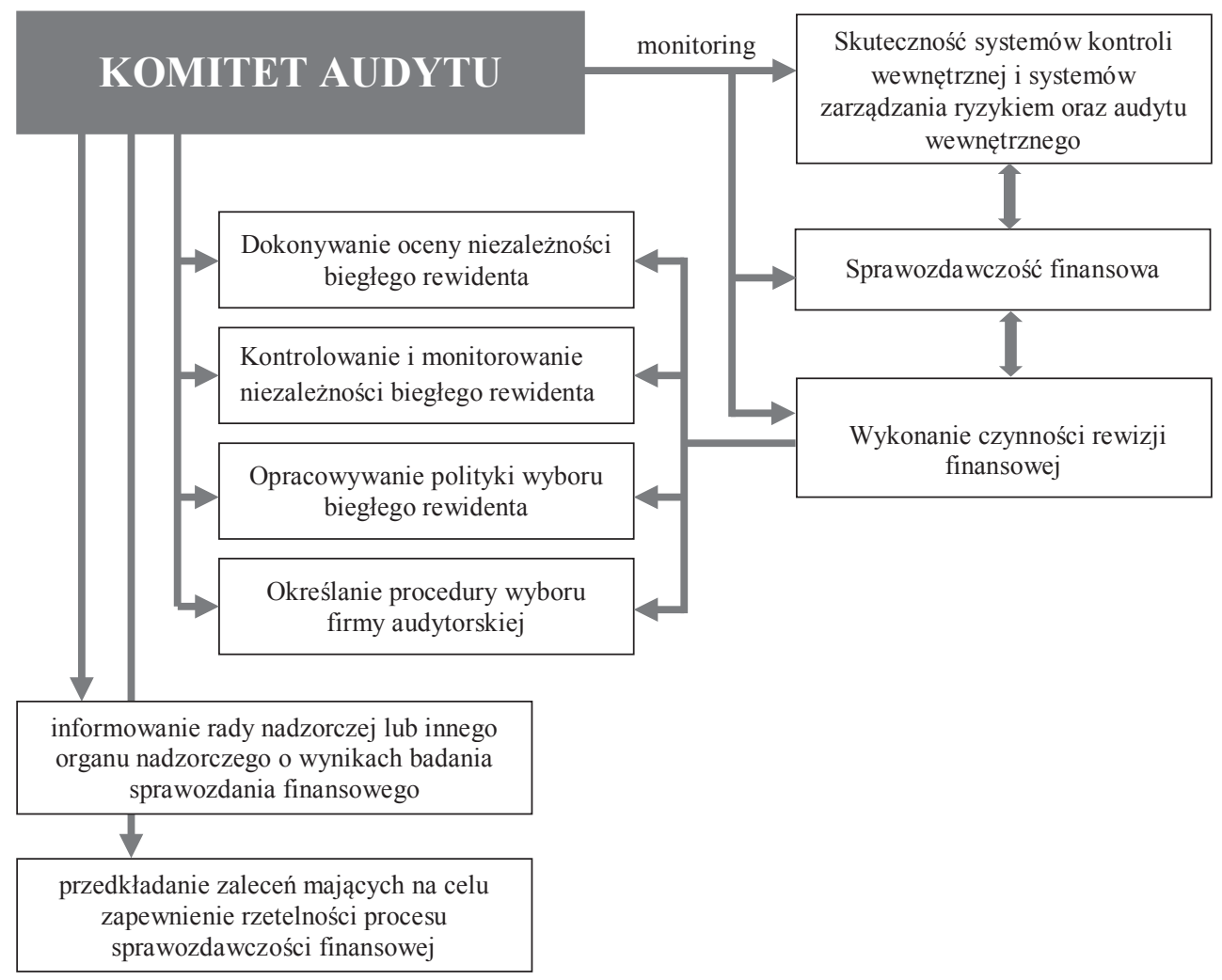

Rys. 1. Zakres zadań komitetu audytu

Źródło: opracowanie własne. 
Przyjmując słownikowe znaczenie słowa „monitoring”, rozumianego jako stały nadzór, obserwację i kontrolę nad procesami lub zjawiskami, zadania komitetu audytu nabierają szczególnego znaczenia [Słownik PWN]. Pierwszym z wymienionych przez ustawodawcę obszarów podlegających monitorowaniu jest proces sprawozdawczości finansowej. Z kontekstu zapisu należy wnioskować, że chodzi tu o sprawozdawczość finansową w ujęciu pragmatycznym, czyli z uwzględnieniem jej znaczenia w procesie przekazywania informacji o jednostce jej interesariuszom, którzy wykorzystują je do podejmowania decyzji biznesowych. Spełnienie tego wymogu wymaga od komitetu audytu nadzorowania nie tylko procesu sporządzania sprawozdania finansowego, ale również sposobu prowadzenia ksiąg rachunkowych i czynności inwentaryzacyjnych. Tak pojmowany proces monitorowania sprawozdawczości finansowej może w praktyce stanowić dla komitetu audytu duże wyzwanie, gdyż, co warto podkreślić, jego członkowie nie są pracownikami jednostki, a obowiązek zwoływania rady nadzorczej (a zatem i komitetu audytu) wynikający z zapisów kodeksu spółek handlowych uzależniony jest od potrzeb w tym zakresie, nie rzadziej jednak niż trzy razy w roku obrotowym.

W tym miejscu powstaje pytanie, czy monitoring sprawozdawczości finansowej, o której mówi ustawodawca w art. 130 ust. 1, obejmuje także oświadczenie na temat informacji niefinansowych, które są obligatoryjnym składnikiem sprawozdania finansowego jednostki zainteresowania publicznego, począwszy od sprawozdań finansowych sporządzonych za 2017 r. Ustawa o biegłych rewidentach, firmach audytorskich oraz nadzorze publicznym nie zawiera wprost odpowiedzi na to pytanie. Odwołując się jednak do zapisów kodeksu spółek handlowych [Ustawa z dnia 15 września 2000 r., art. 382 ust. 3], które wskazują, że do szczególnych obowiązków rady nadzorczej należy ocena sprawozdania zarządu z działalności jednostki oraz sprawozdania finansowego za rok ubiegły, należy skłonić się ku odpowiedzi twierdzącej. Prawidłowość przyjętego stanowiska potwierdza także fakt, że ustawodawca zobligował komitet audytu do nadzoru systemu kontroli wewnętrznej i systemów zarządzania ryzykiem oraz audytu wewnętrznego [Rybicki 2018, s. 13].

Do zadań komitetu audytu należy również monitoring czynności rewizyjnych w szczególności przeprowadzania badania przez firmę audytorską [Ustawa z dnia 11 maja 2017 r., art. 128 ust. 1 pkt 3]. Zadaniem biegłych rewidentów podczas badania jest weryfikacja poprawności sporządzenie sprawozdania finansowego, które jest głównym źródłem informacji o jednostce dla jej interesariuszy. Znaczenie sprawozdań finansowych w procesie podejmowania decyzji gospodarczych przez szeroko rozumiane otoczenie przedsiębiorstwa (kontrahentów, instytucje finansowe, urzędy) sprawiło, że jakość danych sprawozdawczych i rzetelność samych sprawozdań stały się priorytetem. Rolą komitetu audytu jest także dbanie, by biegły przeprowadzający badanie posiadał odpowiednie kwalifikacje i doświadczenie, w szczególności w branży, w której działa jednostka, oraz spełniał kryterium niezależności. Ustawodawca zobligował komitet audytu do opracowania polityki wyboru firmy audytorskiej przeprowadzającej badanie i określenia procedury wyboru 
firmy audytorskiej przez jednostkę zainteresowania publicznego oraz do dokonania oceny niezależności biegłego rewidenta i wyrażenia zgody na świadczenie przez niego usług dozwolonych niebędących badaniem, zgodnie z przyjętą przez firmę audytorską polityką świadczenie takich usług. Włączenie komitetu audytu w proces wyboru firmy audytowej i biegłego przeprowadzającego badanie ma na celu zwiększenie rzetelności i przejrzystości tych procedur.

W trakcie badania biegły rewident na bieżąco komunikuje się z osobami sprawującymi nadzór. Zobligowany jest do poinformowania osób sprawujących nadzór o formie i terminach oraz przewidywanej ogólnej treści przekazu informacji. Wybór formy komunikacji ustawodawca pozostawił do zawodowego osądu biegłego, przy czym sprawy przekazywane ustnie włączane są do dokumentacji wraz z informacją o terminie i osobie, której te informacje zostały przekazane [Krajowy Standard Badania 260(Z) pkt. 18-22].

Biegły rewident oprócz sprawozdania $\mathrm{z}$ badania, które zastąpiło dotychczasową opinię z badania, przygotowuje sprawozdanie dodatkowe dla komitetu audytu. Na przedstawione sprawozdanie dodatkowe oraz rozmowę $\mathrm{z}$ audytorem komitet audytu informuje radę nadzorczą lub inny organ nadzoru nadzorczy lub kontrolny jednostki zainteresowania publicznego, w jaki sposób przeprowadzone badanie przyczyniło się do zapewnienia rzetelności sprawozdawczości finansowej jednostki i jaką rolę w procesie badania pełnił komitet audytu. Jest on także uprawniony do przedkładania zaleceń w tym zakresie.

\section{Jakość sprawozdań finansowych sporządzanych według MSSF}

Szukając odpowiedzi na pytanie o zasadność wprowadzenia obowiązku wyłonienia $\mathrm{z}$ rady nadzorczej komitetu audytu, autorka sięgnęła do przygotowanego przez Komisję Nadzoru Finansowego raportu „Nadzór nad sprawozdawczością finansową emitentów papierów wartościowych prowadzony w 2017" prezentującego wyniki przeprowadzonego badania sprawozdań finansowych wybranych emitentów pod kątem oceny ich zgodności z obowiązującymi zasadami raportowania finansowego oraz podejmowaniem odpowiednich środków w celu eliminacji naruszeń obowiązków informacyjnych. Z raportu wynika, że w 2016 r. odnotowano spadek liczby emitentów, których sprawozdania z badania sprawozdań finansowych zawierały zastrzeżenie. Wzrosła natomiast liczba podmiotów, którzy otrzymali odmowę wyrażenie opinii przez firmę audytorską (rys. 2).

Analiza tematyki zastrzeżeń zawartych w sprawozdaniu $\mathrm{z}$ badania sprawozdań finansowych za rok 2016 i pierwsze półrocze 2017 r. wykazała, że w kolejnych okresach zagadnienia problemowe powtarzają się (rys. 3, rys. 4). 


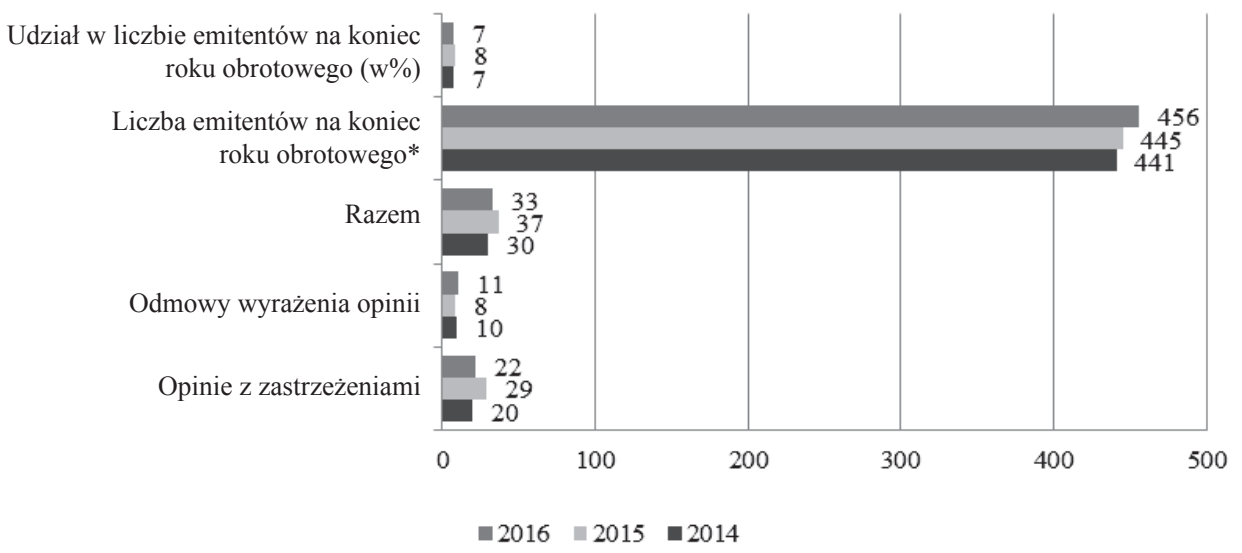

* podana liczba nie obejmuje notowanych na rynku regulowanym funduszy inwestycyjnych zamkniętych oraz emitentów dla których Rzeczpospolita Polska jest państwem przyjmującym.

Rys. 2. Liczba emitentów na rynku regulowanym, liczba odmów wyrażenia opinii przez biegłego lub wyrażenie opinii z zastrzeżeniami w sprawozdaniu z badania sprawozdania finansowego

Źródło: opracowanie własne na podstawie: Nadzór nad sprawozdawczościa finansowa emitentów papierów wartościowych prowadzonych w 2017 roku, KNF, Warszawa 2018.

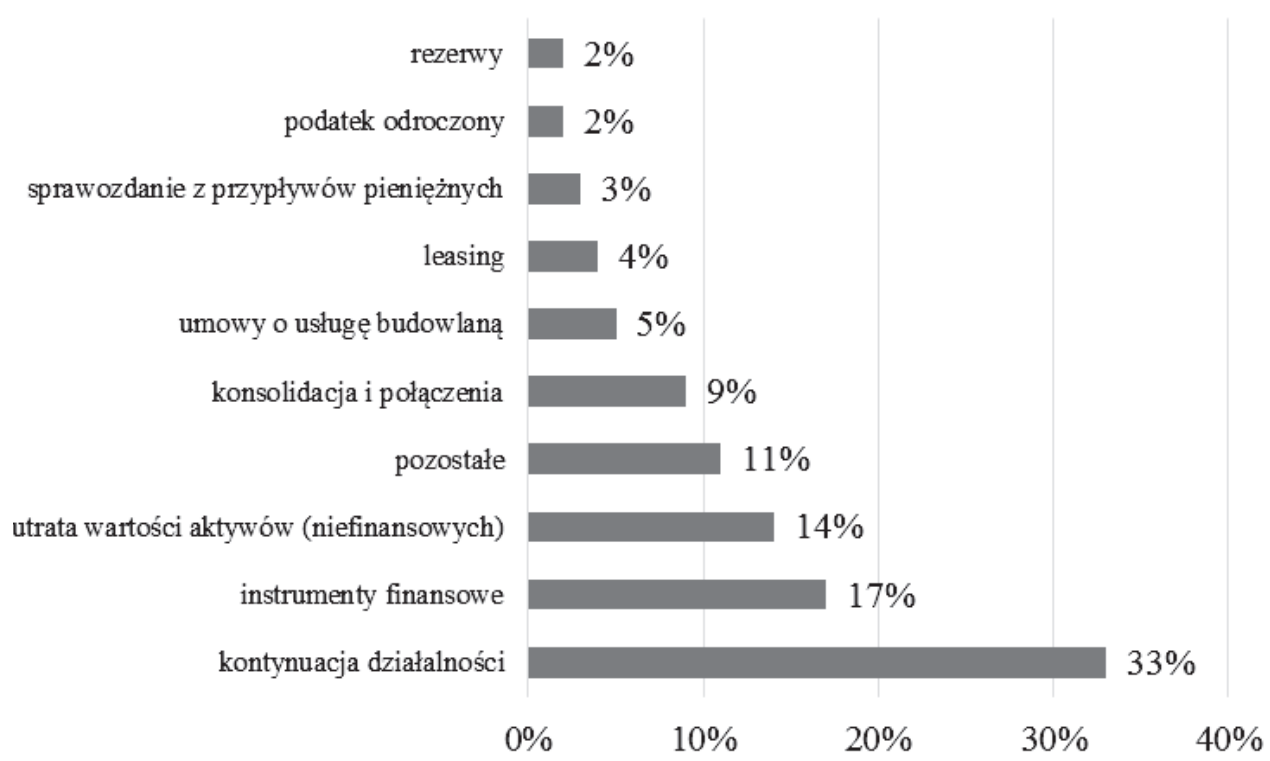

Rys. 3. Tematyka zastrzeżeń zawartych w sprawozdaniu z badania rocznych sprawozdań finansowych za 2016 r.

Źródło: opracowanie własne na podstawie: Nadzór nad sprawozdawczościa finansowa emitentów papierów wartościowych prowadzonych w 2017 roku, KNF, Warszawa 2018. 


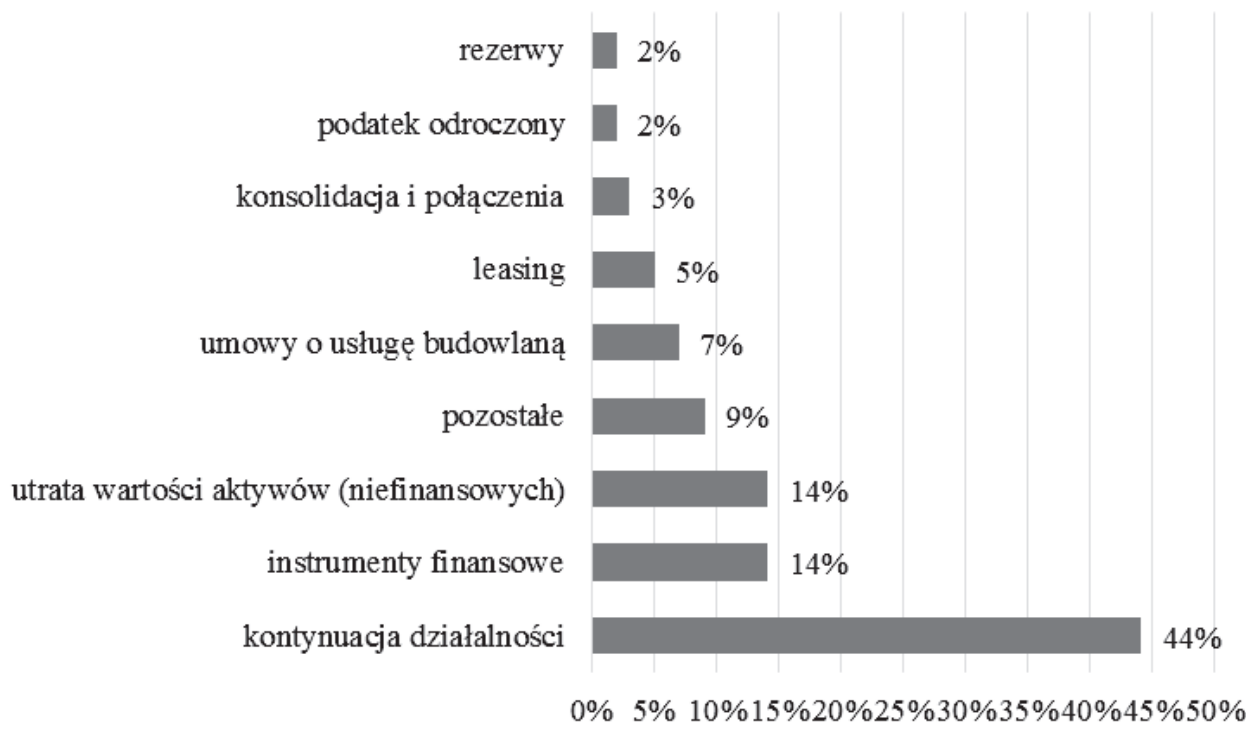

Rys. 4. Tematyka zastrzeżeń zawartych w raportach z przeglądu sprawozdań finansowych emitentów za I półrocze 2017

Źródło: opracowanie własne na podstawie: Nadzór nad sprawozdawczościa finansowa emitentów papierów wartościowych prowadzonych w 2017 roku, KNF, Warszawa 2018.

Najwięcej zastrzeżeń dotyczyło kontynuacji działalności przez jednostkę, instrumentów finansowych oraz utraty wartości aktywów niefinansowych. W tym miejscu należy zauważyć, że zagadnienia te są wzajemnie powiązane. Zagrożenie lub chociażby niepewność co do kontynuacji działalności przez jednostkę przekłada się na wzrost towarzyszącego jej ryzyka, także w obszarze instrumentów finansowych, co wpływa na wycenę posiadanych przez jednostkę aktywów finansowych i niefinansowych. Z drugiej strony problemy przedsiębiorstwa skutkujące koniecznością zastosowania odpisów z tytułu utraty wartości czy zwiększające się ryzyko w odniesieniu do instrumentów finansowych może skutkować wzrostem niepewności czy zagrożenia dla kontynuacji działalności jednostki. Najmniejsza liczba zastrzeżeń zawartych w sprawozdaniu z badania sprawozdania finansowego dotyczyła rezerw i podatku odroczonego [KNF 2018].

Znaczenie jednostek zainteresowania publicznego sprawia, że ich sprawozdanie finansowe będące głównym narzędziem komunikacji z otoczeniem powinno być rzetelne, wiarygodne i wolne od błędów. Niestety, jak wynika z zaprezentowanych wyników badań, sprawozdania finansowe zawierają błędy skutkujące wydaniem przez biegłych w sprawozdaniach $\mathrm{z}$ badania opinii z zastrzeżeniem lub odmowy wydania opinii. Tematyka wydanych zastrzeżeń powiela się w kolejnych latach. 


\section{Podsumowanie}

Wprowadzenie obowiązku powołania stałego komitetu ds. audytu w ramach organów nadzorczych (rad nadzorczych) jest zasadne z wielu powodów. Po pierwsze, odnosząc się do teorii nadzoru korporacyjnego, wymóg ten wynika z roli rad nadzorczych jako wewnętrznego mechanizmu nadzoru. W literaturze przedmiotu odnaleźć można zaproponowane przez różnych autorów zestawienia ról rad nadzorczych [Selznick 1957; Mace 1971; Pfeffer 1972; Fama, Jensen 1983; Mintzberg 1983; Einsenhardt 1988; Hung 1998]. W praktyce jednak trudno zakładać, że rada nadzorcza pełni jedną, konkretną rolę lub jeden zestaw ról opisany w literaturze przedmiotu. Jest to raczej indywidualna dla każdej rady nadzorczej wypadkowa wielu czynników, do których w szczególności należy zaliczyć: obowiązujące w danym czasie przepisy prawa, charakteru jednostki, właścicieli i innych interesariuszy, branży, w której funkcjonuje jednostka, oraz wiedzy merytorycznej, doświadczenia i cech osobowościowych członków rad.

Zgodnie z obowiązującymi zapisami kodeksu spółek handlowych rada nadzorcza prowadzi stały nadzór nad wszystkimi dziedzinami działalności jednostki, a zatem także nad sprawozdawczością finansową [Ustawa z dnia 15 września 2000 r., art. 382 ust. 1]. Nie wszyscy członkowie rady nadzorczej muszą być jednak specjalistami w zakresie rachunkowości, dlatego mogą mieć trudności w ocenie prawidłowości sporządzonych sprawozdań finansowych oraz egzekwowania terminowości wypełniania obowiązków sprawozdawczych przez jednostkę. Komitet audytu złożony z co najmniej trzech członków, z których co najmniej jeden posiada wiedzę i umiejętności w zakresie rachunkowości lub badania sprawozdań finansowych, pełni funkcję pomocniczą i doradczą dla rady nadzorczej w obszarze rachunkowości i sprawozdawczości. Nie należy bowiem zapominać, że rada nadzorcza na równi z kierownictwem firmy ponosi odpowiedzialność za sprawozdanie finansowe jednostki.

Posiadana przez członków komitetu audytu wiedza jest także niezwykle pomocna w kontaktach z biegłymi badającymi sprawozdania finansowe jednostki. Biegły ma bowiem możliwość przekazywania na bieżąco informacji o przebiegu badania, komunikując organ nadzorczy np. o istotnych trudnościach napotkanych w czasie badania, o istotnych sprawach, które były przedmiotem jego korespondencji z kierownictwem firmy, zidentyfikowanych ryzykach itd., i ma pewność, że jego uwagi zostaną przeanalizowane przez kompetentne osoby.

Globalizacja gospodarki, szybki rozwój technologii oraz dynamika zmian zachodzących w otoczeniu jednostek funkcjonujących na rynku $\mathrm{z}$ jednej strony, $\mathrm{z}$ drugiej zaś potrzeba rozszerzenia informacji sprawozdawczej wynikająca $\mathrm{z}$ takich teorii przedsiębiorstwa jak: teoria interesariuszy, legitymizacji, społecznej odpowiedzialności czy koncepcji pełnej przejrzystości działania przedsiębiorstwa sprawiły, że od kilku lat trwają dyskusje nad celem i zakresem sprawozdawczości przedsiębiorstw. Obecnie można wyróżnić dwa kierunki rozwoju sprawozdania fi- 
nansowego: teoria transakcyjna skupiająca się na prezentacji osiągniętej przez jednostkę rentowności oraz teoria wartości przedsiębiorstwa, której głównym celem jest prawidłowe ustalenie wartości kapitału własnego [Turyna 2006]. W świetle przedstawionych koncepcji dane zawarte w sprawozdaniu finansowym wynikające z przyjętej polityki rachunkowości (m.in. kwalifikacja zasobów, moment ujęcia w księgach rachunkowych, wycena wartości szacunkowych itd.) i właściwa ich interpretacja, nabiera szczególnego znaczenia. Komitet audytu także w tym przypadku może być pomocny w prawidłowej realizacji zadań powierzonych radzie nadzorczej [Al-Baidhani 2014; Sultana i in. 2015].

W tym miejscu pojawia się pytanie, czy posiadanie przez prezesa i członków zarządu rozległej wiedzy z zakresu rachunkowości i finansów jest korzystne dla przedsiębiorstwa. Z jednej strony na pewno tak. Wiedza pozwoli bowiem na optymalizację działania przedsiębiorstwa, zwłaszcza w zakresie identyfikacji źródeł kosztów i ich optymalizacji. Z drugiej jednak strony, wiedząc, że głównym kryterium oceny efektywności ich działania jest EBITDA lub (choć rzadziej) zysk netto przedsiębiorstwa, zarząd może pojmować działania maksymalizujące zyski w krótkim okresie. Bolączką dużych przedsiębiorstw, nie tylko polskich, jest fakt, że zarząd jednostki zmienia się średnio co 2, 3 lata, a rezultaty podjętych działań w takich podmiotach widoczne są po około 1,5-2 latach, kiedy ówczesnego kierownictwa już w przedsiębiorstwie nie ma. Powoduje to, że kierownictwo firmy skupione jest na maksymalizacji wyników krótkookresowych, a nie na realizacji strategii przedsiębiorstwa w długim okresie. Przedsiębiorstwo natomiast, by móc rozwijać się w sposób zrównoważony, potrzebuje silnego i stabilnego kierownictwa.

Doniosłość zadań komitetu audytu sprawia, że osoby będące jego członkami powinny cechować się między innymi: poczuciem odpowiedzialności, odwagą w wyrażaniu własnych opinii, asertywnością, a także posiadać wysokie standardy etyczne i umiejętność holistycznego spojrzenia [Błaszkowski i in, 2011]

\section{Literatura}

Al-Baidhani A., 2014, The Role of Audit Committee in Corporate Governance: Descriptive Study, August 26, https://ssrn.com/abstract=2487167.

Błaszkowski G., Czerwieniec M., Koska Ł., Majek W., Nekanda-Trepka P., Ostrowski C., Spiechowicz P., 2011, Komitet Audytu - pierwsze kroki. Przewodnik dla praktyków, Giełda Papierów Wartościowych w Warszawie S.A., GPW, s. 23.

Eisenhardt K.M., 1989, Agency theory: An assessment and review, Academy of Management Review, Vol. 14, no. 1, s. 57-74.

Expertise, 2015, Accounting and Finance 55, s. 279-310.

Fama E., Jensen M., 1983, Separation of ownership and control', Journal of Law and Economics, Vol. 26, s. 301-325.

Hung H.A., 1998, Typology of the Theories of the Roles of Governing Boards. Corporate Governance, $6(2), 103-104$. 
Krajowy Standard Badania 260 (Z) w brzmieniu Międzynarodowego Standardu Badania 260 (zmienionego) „Komunikowanie się z osobami sprawującymi nadzór”.

Mintzberg H., 1983, Power In and Around Organizations, Prentice-Hall.

Nadzór nad sprawozdawczościa finansowa emitentów papierów wartościowych prowadzonych w 2017 roku, 2018, Komisja Nadzoru Finansowego, Warszawa.

Pfeffer J., 1972, Size and composition of corporate boards of directors: The organization and its environment, Administrative Science Quarterly, s. 218-228.

Rozporządzenie Parlamentu Europejskiego i Rady (UE) NR 537/2014 z dnia 16 kwietnia 2014 r. w sprawie szczegółowych wymogów dotyczących ustawowych badań sprawozdań finansowych jednostek interesu publicznego, uchylające decyzję Komisji 2005/909/WE.

Rybicki P., 2018, Funkcje komitetu audytu, Rachunkowość, nr 3, Stowarzyszenie Księgowych w Polsce, Warszawa, s. 13.

Selznick P., 1957, TVA and the Grass Roots, University of California Press.

Słownik PWN, https://sjp.pwn.pl/sjp/monitoring;2568296.html (dostęp: 15.05.2018).

Sultana N., Mitchell Van der Zahn J.-L., 2015, Earnings conservatism and audit committee financial expertise, Accounting \& Finance. 55, s. 280.

Turyna J., 2006, Standardy sprawozdawczości finansowej, Difin, Warszawa, s. 52.

Ustawa z dnia 7 maja 2009 r. o biegłych rewidentach i ich samorządzie, podmiotach uprawnionych do badania sprawozdań finansowych oraz o nadzorze publicznym, Dz.U. z 2009, nr 77, poz. 649.

Ustawa z dnia 11 maja 2017 r. o biegłych rewidentach, firmach audytorskich oraz nadzorze publicznym, Dz.U. z 2017 r. poz. 1089.

Ustawa z dnia 15 września 2000 r. - Kodeks spółek handlowych, Dz.U. z 2017 r. poz. 1577. 